\title{
Kommas en betekenis
}

'n Mens besef nie altyd watter betekenisverskil 'n komma of twee in 'n sin kan maak nie. In hierdie rubriek kyk ek na twee gebruike waarmee dikwels gefouteer word.

In Afrikaans (wat in dié opsig van Engels verskil) word 'n byvoeglike bysin tradisioneel met ' $n$ komma afgesluit as dit nie die einde van die betrokke sin uitmaak nie. Dit is bysinne wat met 'n betreklike voornaamwoord begin, soos wat, waarvan, wie se, vir wie, waarmee en so meer, byvoorbeeld:

1. Die haan wat op die kerktoring staan, is van brons gemaak.

2. Die gesin wie se huis afgebrand het, is nou haweloos.

3. Die motor waarvan 'n band gebars het, het omgeslaan.

Dié komma maak deel van Afrikaans se punktuasietradisie uit en vervul ook die rol van die ou Afrikaanse reël dat'n komma geplaas word tussen werkwoorde wat tot verskillende sinsdele behoort, selfs al staan daardie twee werkwoorde nie direk langs mekaar nie. Dit is jammer dat dié tradisie en reël deesdae na willekeur geïgnoreer word, veral in die pers.

Soms kan daar egter ook 'n komma vóór so ’n bysin geplaas word en dit verander die betekenis en aard van die bysin. Kyk byvoorbeeld na die volgende sinne:

4. My kinders wat in Brittanje woon, verlang huis toe.

5. My kinders, wat in Brittanje woon, verlang huis toe.

Een van my ou leermeesters, prof. Meyer de Villiers, het die tipe van voorbeelde 1 tot 4 "beperkende byvoeglike bysinne" genoem, want hulle beperk die betekenis van die selfstandige naamwoord waarby hulle pas. Die tipe 5-voorbeeld - dit wil sê dié wat ook 'n komma voor die betreklike voornaamwoord het - het hy "aanvullende" of "uitbreidende byvoeglike bysinne" genoem, want hulle gee aanvullende inligting wat teoreties weggelaat kan word of wat in 'n afsonderlike sin gegee kan word. In Engels word hulle onderskeidelik "restrictive" en "nonrestrictive clauses" genoem.

In $\sin 4$ beperk die bysin ("wat in Brittanje woon") die betekenis van "My kinders", want die spreker impliseer dat sy/haar kinders wat elders as in Brittanje woon, byvoorbeeld in Kaapstad of Australië, nie huis toe verlang nie: slegs dié wat in Brittanje woon, verlang huis toe. Die implikasie is voorts dat die spreker nog kinders benewens dié in Brittanje het. Die bysin is dus beperkend want dit beperk die betekenis van "my kinders" tot dié in Brittanje.

In sin 5, daarenteen, gee die spreker te kenne dat (al) sy/haar kinders huis toe verlang en voeg hy/sy as 'n bystelling by dat die kinders in Brittanje woon - aanvullende of uitbreidende inligting, dus, wat ook in 'n afsonderlike sin verstrek sou kon word, byvoorbeeld:

6. My kinders verlang huis toe. Hulle woon in Brittanje.

$\mathrm{OF}$

7. My kinders verlang huis toe; hulle woon in Brittanje.

Hierdie verskil kom heel dikwels voor, byvoorbeeld:

8. Die droogte het die saaiboere wat vroeg gesaai het, geknel.

9. Die droogte het die saaiboere, wat vroeg gesaai het, geknel. 
Sin 8 beperk die betekenis tot slegs die saaiboere wat vroeg gesaai het, maar nie dié wat byvoorbeeld laat gesaai het nie, terwyl sin 9 impliseer dat die droogte al die saaiboere geknel het en bykomend of aanvullend, amper terloops, sê dat hulle vroeg gesaai het.

Dieselfde soort verskil kom ook voor by ander soorte bystellings wat ek hier "apposisies" of "apposisionele konstruksies" noem (omdat hulle nie werkwoorde bevat nie en dus nie bysinne is nie), nl. beperkende en aanvullende/uitbreidende apposisies. Gewoonlik is die tweede konstruksie dan 'n verklarende of onderskeidende bystelling by die eerste konstruksie.

Ook hier kan kommas 'n beduidende betekenisverskil maak. Vergelyk:

10. My suster Anna is 'n chirurg.

11. My suster, Anna, is 'n chirurg.

In sin 10 is die implikasie dat die spreker minstens nog een ander suster het, maar dat die een genaamd Anna 'n chirurg is. In sin 11 impliseer die spreker dat hy/sy net een suster het en dat dié 'n chirurg is. As aanvullende of uitbreidende inligting word die suster se naam verstrek. Dit word onderskeidelik beperkende en aanvullende apposisies genoem.

Die kommas, al dan nie, maak dus 'n belangrike betekenisverskil, byvoorbeeld:

12. Die DA-leier, Mmusi Maimane, stem saam. [aanvullend/uitbreidend/niebeperkend]

13. Die DA-leier Mmusi Maimane stem saam (maar nie die DA-leier HZ nie). [beperkend; betekenisgewys hier waarskynlik foutief]

14. Die beroemde komponis, Ludwig van Beethoven, het geskryf ... [aanvullend; dit impliseer daar was slegs een beroemde komponis, $n l$. Beethoven - foutief]

15. Die beroemde komponis Ludwig van Beethoven (nie die beroemde komponis Mozart nie) het geskryf ... [beperkend; korrek]

16. Die Hertzogpryswenner Pieter-Dirk Uys vertel ... [beperkend; korrek] MAAR

17. Vanjaar se Hertzogpryswenner vir Drama, Pieter-Dirk Uys, vertel ... [aanvullend; korrek]

Kyk gerus ook in die jongste $A W S$, bll. 121 en 122, reël 13.33, veral opmerking (b).

Dis die klein jakkalsies wat soms 'n groot verskil kan maak!

JD (Tom) McLachlan

E-pos: tommcl@whalemail.co.za

\section{BRONNE:}

De Villiers, M. 1968. Die grammatika van tyd en modaliteit. Kaapstad: AA Balkema. De Villiers, M. 1983. Afrikaanse grammatika vir volwassenes. Goodwood: Nasou.

Quirk, R. \& Greenbaum, S. 1973 (1988). A university grammar of English. Harlow: Longman.

Shorter Oxford English Dictionary. 2002, 2007. 6 ed. Oxford: OUP.

Taalkommissie, SAAWK. 2017. Afrikaanse woordelys en spelreëls. Kaapstad: Pharos. 